\title{
ANCA GIURCHESCU
}

(1930-2015)

\author{
CHARISMA, TRUE INTEREST AND THE WISDOM \\ OF ACCEPTING, THAT ONE IS NOT THE TRUTH-KEEPER...
}

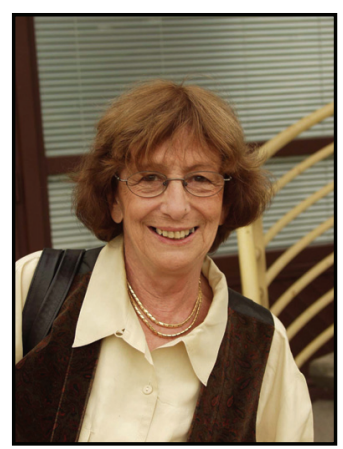

Dr Anca Giurchescu, internationally renowned Romanian ethnochoreologist, honorary chair of the Study Group on Ethnochoreology of ICTM, doctor honoris causa of the Roehampton University (London), former senior researcher of the Institute for Ethnography and Folklore of the Romanian Academy of Sciences, Foreign Honorary Member of the Hungarian Ethnographical Society, passed away on $4^{\text {th }}$ April 2015.

She studied rhythmic dance at the University of Physical Education in Bucharest from 1949. In 1953 she obtained a research position in the Choreology Department of the Institute of Ethnography and Folklore. During her time at the institute Anca contributed to the foundation and development of folk dance research in Romania, conducting fieldwork in over 240 localities. By the time she left the department in 1979 she was senior researcher. That year Anca left Romania and was granted political refugee status in Denmark, where she remained active as a dance scholar. She returned to her homeland in 1989, after the collapse of the communist regime, to continue her research (started in 1968) on the process of transformation of the ritual Călus, and on the dance tradition of the Roma minority. Besides, she touched upon several other research topics: relationship between dance and politics, dance as ethnic symbol, minority-majority questions and folk dances in the context of stage perfomance, principles of the structural analysis, structural typology and classification of the dances, the process of dance creation, improvisation, learning, transmission. She investigated, from an insider's perspective, the way traditional symbols were manipulated by communist cultural management for political power legitimation. About these topics she published more than a hundred writings. (See some remarkable ones at the end of the obituary.)

We are certain that all these details will be mentioned in any encyclopaedia dealing with anthropology, folklore, and especially ethnochoreology, both in Europe and in the world. But what they will ignore is her unforgettably nice personality, her enthusiasm in 
research and inexhaustible energy in capacity building in ethnochoreological research. Writers of future encyclopaedia entries will omit her commitment to the education and training of the next generation of choreologists. Although she did not have a university chair anywhere in the world, still she had more students from the USA to England, Norway, Romania and Hungary, who declare themselves as Anca's students, than anybody from her generation. She was in the staff of the Intensive Programs of Education on Ethnochoreology held in Trondheim University (Norway) (with the participation of fifteen European universities). She charmed the students with her informal style of presentation, her huge amount of direct experience from the field and her ability to interpret her documents in a witty way.

Encyclopaedias do not say a word about her zeal for making field research. To collect new field experiences about dance and dancing was perhaps her most favourite activity in life. When on the field she did not care about her weakening muscles and the breath running short in her lungs. As leader of the Sub-Study Group on Fieldwork Methodology, she established several worldwide workshops for members of the ICTM Study Group on Ethnochoreology, where participants could experience fieldwork and could share their previous knowledge at the highest professional level.

Hungarian ethnochoreologists remember her because of her strong professional relations and collaboration with György Martin in the 1960-1970s. Her connections did not cease after Martin's death. She made friends with the new generation of folk dance researchers as well and the collaborations with them resulted in several field researches in Hungary and Romania.

We, dance researches are very grateful to her for all her work and sacrifice, and we will do our best to keep up her work and sacrifice, and we will memory as long as we can.

László Felföldi

Some of her best known works:

The Dance Discourse: Dance Suites and Dance Cycles of Romania and Elsewhere in Europe. Dance Studies 11, 9-71. Jersey, Channel Islands, United Kingdom: Centre for Dance Studies (1987).

Theory and Methods in Dance Research: A European Approach to the Holistic Study of Dance. Yearbook for Traditional Music 23, 1-10. International Council for Traditional Music (with Lisbet Torp) (1991).

Romanian Traditional Dance: A Contextual and Structural Approach. Wild Flower Press, 427 pages (with Sunny Bloland) (1995).

Experiencing the Field: Fieldwork Research Theory, Methods and Experience. In: Anne Margrete Fiskvik and Marit Stranden (Eds.): (Re)Searching the Field. Festschrift in Honor of Egil Bakka, 213-226. Fagbokforlaget (2014). 
VARIOUS STUDIES 